\title{
Small Vertical Axis Wind Turbines for Energy Efficiency of Buildings
}

\author{
Marco Casini
}

\begin{abstract}
The integration of renewable resources in buildings is a fundamental aspect of the 21st-century architecture in order to achieve zero energy buildings (ZEB), reduce the consumption of fossil energy and cut carbon emissions in urban areas.

Besides photovoltaic systems, nowadays Vertical Axis Wind Turbines, whose business is growing globally, are becoming particularly interesting because of the potential to produce energy and to be building integrated.

These small wind generators $(200 \mathrm{~W}-10 \mathrm{~kW})$ can be used as stand-alone systems or as grid connected systems, and both can be paired with other energy conversion systems, such as photovoltaics.

With a height from 2 to 10 meters, small wind turbines can be placed on rooftops, on streets or in gardens, they have relatively little visual impact and are able to produce energy even from modest wind flows. In addition to that, small wind turbines may also be coupled to street lighting systems (smart lighting).

The article presents an analysis of the different types of vertical wind turbines available on the market, including investigational products, and illustrates how it is possible to install them on buildings (Building Augmented Wind Turbines) and the benefits achieved in terms of energy production compared to photovoltaic systems.
\end{abstract}

Index Terms-Energy efficiency of buildings, renewable energy, small wind turbines, building integrated wind turbines, building augmented wind turbines, vertical axis wind turbines.

\section{INTRODUCTION}

Wind power has been growing dramatically since the beginning of the 21 st century. The global installed capacity at the end of 2013 was around $318 \mathrm{GW}$, up from $18 \mathrm{GW}$ at the end of the 2000 [1]. Around $35 \mathrm{GW}$ of new wind capacity were added in 2013, the lowest growth since 2008, after 44 $\mathrm{GW}$ in 2012. Over the last couple of years, wind's center of growth has been moving from Europe and North America to Asia, which emerged as the global leader. In fact China became the first market in terms of total installed capacity in a very short time, overtaking the United States in 2010. A number of recent important policy measures and programs have emerged in support of the expansion of the wind market, and many of the new policy developments concern offshore wind.

The contribution of wind power to the energy supply has reached a substantial share even on the global level. By the end of 2013 all wind turbines installed around the globe could

Manuscript received September 30, 2014; revised January 29, 2015.

Marco Casini is with the Department of Planning, Design, and Technology of Architecture (PDTA), Sapienza University of Rome, Italy (e-mail: marco.casini@uniroma1.it). have potentially saved a total of 640 terawatt hours to the worldwide electricity supply, more than $4 \%$ of the global electricity demand. In the year 2013, around 103 countries used wind energy for electricity generation.

In 2013 Europe reached $117 \mathrm{GW}$ of wind power capacity, meeting the power needs of 66 million households, equivalent to the output of 45 nuclear power plants - with more than 11 GW added in the last year, a decrease of $8 \%$ compared to 2012 installations caused by market, regulatory and political uncertainty in a number of key markets. The total installed wind power capacity in Europe at the end of 2013 covers $13 \%$ of the EU-27's electricity demand.

By 2020, European Wind Energy Association (EWEA) estimates that $192 \mathrm{GW}$ (including $23 \mathrm{GW}$ offshore) of wind power capacity will be installed in the EU, producing 442 TWh of power, meeting $15 \%$ of the EU's electricity demand (2.9\% from offshore). Wind provides $34 \%$ of electricity in Denmark, while Portugal and Spain get around 20\% of electricity from wind power, followed by Ireland (16\%), Germany (9\%) and Italy (5\%). Ten European countries have agreed to develop an offshore electricity grid in the North Sea to enable offshore wind developments. The turnover of the wind sector around the world has already reached 60 billion $€$ (75 billion US\$) in the year 2011.

According to World Wind Energy Association (WWEA), based on the current growth rates, in 2016, the global capacity is expected to increase up to $450000 \mathrm{MW}$. By the end of 2020 , at least $700^{\prime} 000 \mathrm{MW}$ are expected to be installed globally [2].

Recently, thanks to the development of small wind turbines, quiet and specified for urban use, it is possible to harness wind power for on-site energy generation or domestic production or agricultural districts.

These turbines, reaching a maximum of $20 \mathrm{~kW}$ of power, can also find space on rooftops or in gardens, they have relatively little visual impact and are able to produce energy even from modest wind flows. Moreover, in contrast to large wind turbines, such plants do not require major infrastructures for electricity transmission from utilities and lend themselves to distributed generation of electricity. Small wind systems can be used both as stand-alone systems or as grid connected systems, and both can be paired with other energy conversion systems, such as photovoltaics.

As of the end of 2012, a cumulative total of 806.000 small wind turbines were installed all over the world (excluding two major markets as India and Italy), 76'000 of which were newly erected that year [3]. During 2012, the number of installed small wind turbines grew by $10 \%$.

China continues to overshadow all other major markets, 
including the USA and the UK, with its cumulative installed units of over $5700^{\prime} 000$, which represents $70 \%$ of the world market in terms of total as well as new installed units. According to estimations, around half of the turbines continue to produce electricity in China given that this market started already in the early 1980s.

The globally installed small wind capacity has reached more than $678 \mathrm{MW}$ as of the end of 2012. China accounts for $37 \%$, and the USA for $31 \%$ of this capacity [3].

More than $100 \mathrm{MW}$ of new small wind capacity were added in the year 2012, a global capacity increase of $18 \%$.

\section{VERTICAL AXIS WIND TURBINES}

Small wind turbines can have either horizontal or vertical axis, the latter being of particular interest for the application on buildings. Unlike classic horizontal axis generators, which need to be always aligned to the wind direction, generators with vertical axis rotors (Vertical axis wind turbines, VAWT), thanks to the helical blade profile or the presence of arms, are able to capture incoming wind from any direction, and therefore do not need to be oriented; they can also take advantage from turbulences (Table I). The wind speed necessary for starting is $2-3 \mathrm{~m} / \mathrm{s}$ and the noise is almost zero for normal winds and even for low winds. For small powers up to $1.5 \mathrm{~kW}$, you can install the system directly to the building.

TABLE I: MAIN ADVANTAGES AND DISADVANTAGES OF VAWT COMPARED TO HAWT

\begin{tabular}{l}
\hline VAWT Advantages \\
\hline No yaw mechanisms is needed. \\
A VAWT can be located nearer the ground, making it easier to maintain \\
the moving parts. \\
VAWTs have lower wind startup speeds than typical HAWTs. \\
VAWTs may be built at locations where taller structures are prohibited. \\
VAWTs situated close to the ground can take advantage of locations \\
where rooftops, mesas, hilltops, ridgelines, and passes funnel the wind \\
and increase wind velocity.
\end{tabular}

\section{VAWT Disadvantages}

Most VAWTs have on average a decreased efficiency than a common HAWT, mainly because of the additional drag that they have as their blades rotate into the wind. Versions that reduce drag produce more energy, especially those that funnel wind into the collector area.

Having rotors located close to the ground where wind speeds are lower and cannot take advantage of higher wind speeds above.

Because VAWTs are not commonly deployed due mainly to the serious disadvantages mentioned above, they appear novel to those not familiar with the wind industry. This has often made them the subject of wild claims and investment scams over the last 50 years.

The main advantage of this arrangement is that the wind turbine does not need to be pointed towards the wind. This is an advantage on sites where the wind direction is highly variable, or is perturbed by turbulence.

With a vertical axis, the generator and other primary components can be placed near the ground, with no need for the shaft to support them and easier accessibility for maintenance. The main drawback of a VAWT is that it generally creates drag when rotating into the wind.

It is difficult to mount vertical-axis turbines on shafts, so they are often installed nearer to the base, such as the ground or a building rooftop. The wind speed is slower at a lower altitude, so less wind energy is available for turbine of a given size. Air flow near the ground and other objects can create turbulence, which can introduce issues of vibration, including noise and bearing wear which may increase the maintenance or shorten its service life. However, when a turbine is mounted on a rooftop, the building generally redirects wind over the roof and these can double the wind speed at the turbine. If the height of the rooftop mounted turbine shaft is approximately $50 \%$ of the building height, this will be almost optimum for maximum wind energy and minimum wind turbulence.

Although vertical axis wind turbines can have different shapes, they can be divided in two main groups: the Savonius turbines (1929) working primarily on the aerodynamic drag principle and the Darrieus turbines (1931) were operating on the principle of lift. On the market there are now innovative models, which take advantages of the features of both.

\section{A. Savonius Wind Turbine}

A Savonius is a drag type turbine, commonly used when high reliability is required in many things such as ventilation and anemometers. Because they are a drag type turbine, they are less efficient than the common HAWT. Savonius are excellent in areas of turbulent wind and can self-start at low wind speeds (Fig. 1).
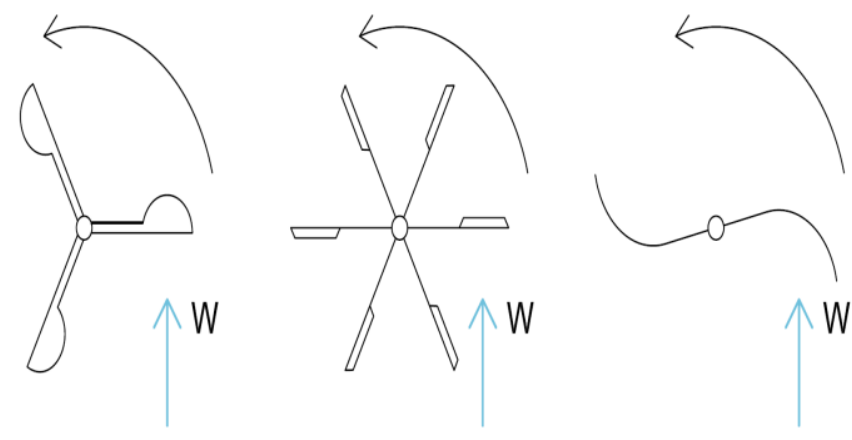

Fig. 1. Savonius wind turbines.

\section{B. Darrieus Wind Turbine}

Darrieus wind turbines are commonly called "Eggbeater" turbines, because they look like a giant eggbeater. They have good efficiency, but produce large torque ripple and cyclic stress on the shaft, which contributes to poor reliability. They also generally require some external power source, or an additional Savonius rotor, to start turning because of the very low starting torque. Torque ripple is reduced by using three or more blades, resulting in a higher solidity of the rotor. Solidity is measured by blade area over the rotor area. Newer Darrieus type turbines are not held up by wires but have an external superstructure connected to the top bearing. Darrieus turbines can either have circular or straight wings (the latter called H-blade Darrieus); a further development has a helicoidal winged design called Gorlov, after its inventor, and it is more efficient (Fig. 2). 


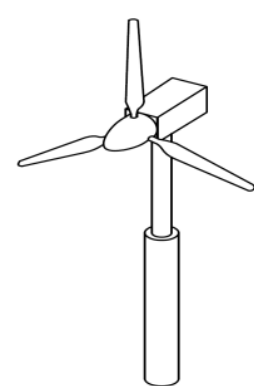

HAWT

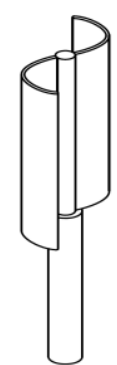

SAVONIUS VAWT

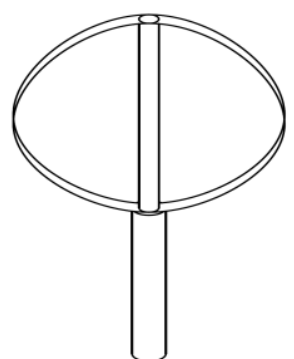

DARRIEUS VAWT

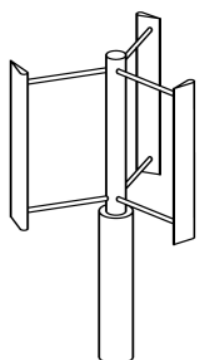

H -BLADE VAWT

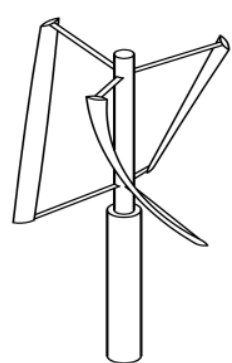

GORLOV VAWT

Fig. 2. Different types of wind turbine.

\section{BuILDING AUGMENTED Wind TURBINES (BAWT)}

Buildings rooftops of can be an excellent location for wind turbines, both because the electric power generation is close to the user and because they allow to take advantages of faster winds while reducing the cost of support towers.

The identification of the turbines position must however be preceded by a thorough analysis of available winds, because turbulences or areas of calm, generated by surrounding buildings or different obstacles located on the roofs (air conditioning systems, antennas), could lead to an energy production significantly lower than expected.

At the same time, it is possible to benefit from the interaction between the wind and the built environment in order to channel air currents to very specific areas where wind turbines can be installed.

Turbines able to exploit the concentration of wind power due to the shape of the building are known as Building Augmented Wind Turbines (BAWT) and their different configurations can be divided in three main groups:

1) BAWT close to the building, on the rooftop or along the sides;

2) BAWT between buildings;

3) BAWT inserted in air conducts through buildings.

In all three cases, the areas of effective availability of air currents are limited in relation to the extension of the surfaces of the buildings, requiring the use of compact and properly located rotors to take advantages of them.

\section{A. BAWT Close to the Building}

BAWT installations close to the building exploit the acceleration of the air flow at the upper corners and the sides of the facade of the building (Fig. 3).

However this phenomenon is followed by the formation of turbulent areas because of the air flow separation, making vertical axis turbines more effective than turbines with horizontal axis.

The consequence of turbulence along the edges of the building may possibly be mitigated by using a curved roof (characterized by adherent, turbulence free air flow), or by placing the turbines on poles or shafts in order to reach the undisturbed air, or by creating spoilers and ailerons integrated into the building envelope, as in the case of Oklahoma Medical Research Foundation Perkins + Will Inc (2012) (Fig. 4) or the Public Utility Commission Headquarters in San Francisco, KMD architects, Stevens and JV (2012) (Fig. 5) and Greenway Self Park building of HOK in Chicago (2010) (Fig. 6).

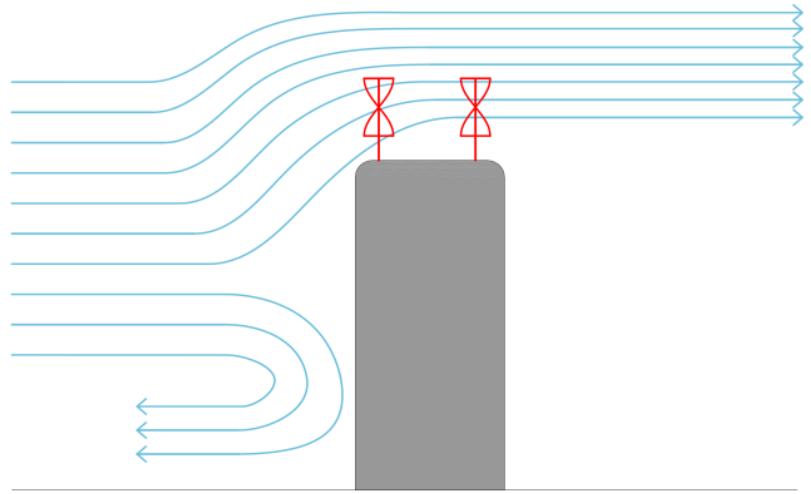

Fig. 3. BAWT close to the building, rooftop mounted.

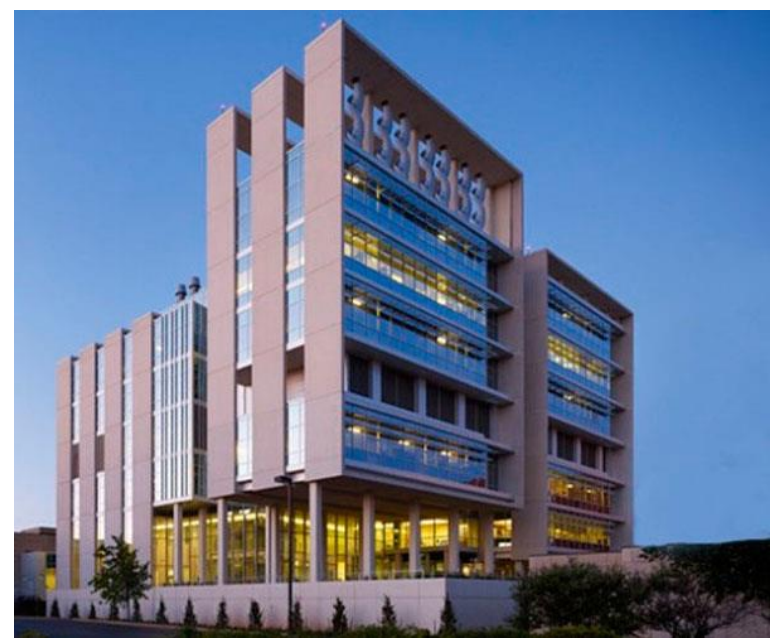

Fig. 4. Oklahoma Medical Research Foundation [4].

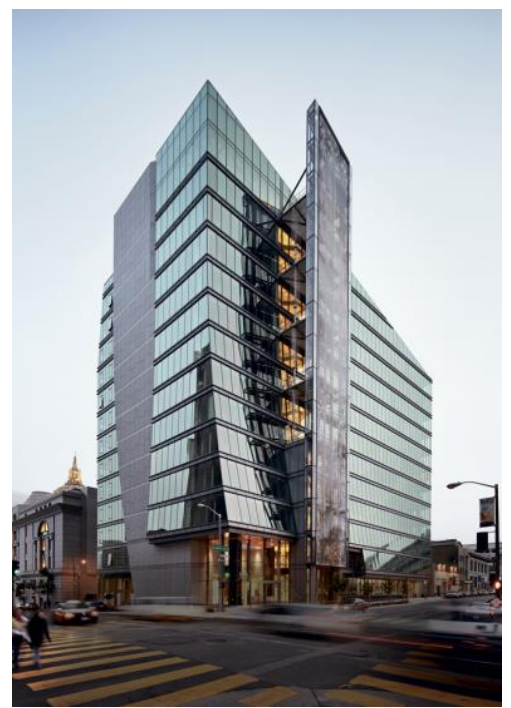

Fig. 5. San Francisco Public Authority Commission Headquarters [5]. 


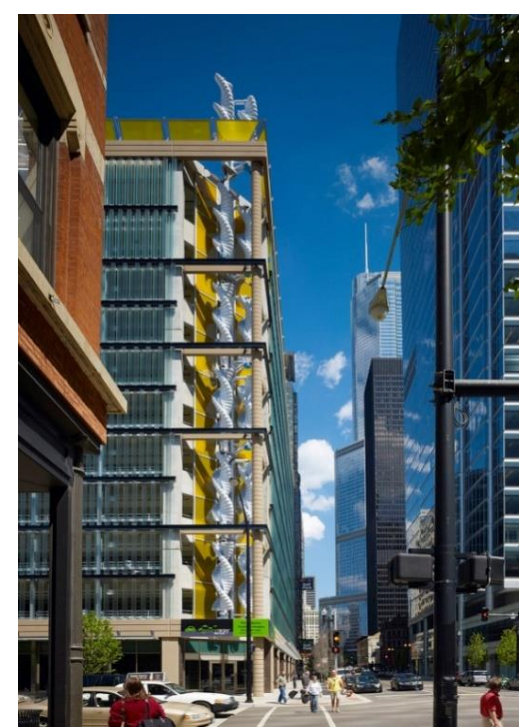

Fig. 6. Greenway Self Park Building - Chicago [6].

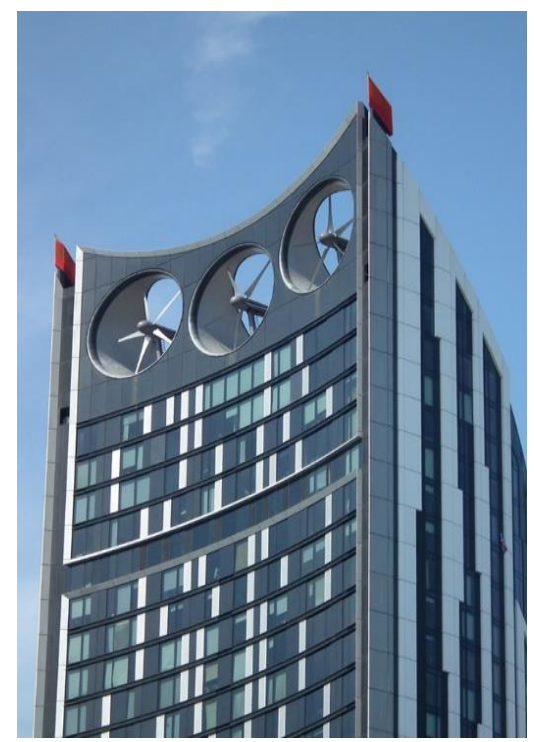

Fig. 7. Strata SE1 - London [7].

The Strata SE1 residential tower in London (Fig. 7), designed by the BFLS and completed in 2010, includes three wind turbines ( $19 \mathrm{~kW}$ each one) in its crown at 148 meters off the ground, able to produce up to $50 \mathrm{MWh} /$ year, enough to power the common spaces of the building ( $8 \%$ of total consumption).

\section{B. BAWT between Buildings}

BAWT between buildings require special integration between the formal architectural design and the systems solution (Fig. 8).

By locating buildings with a specific geometric shape (generally an airfoil profile) at a precise distance, it is possible to make the facades surfaces exposed to the wind contribute to channel the prevailing winds.

The two buildings can be positioned according to the direction of the wind so they can act as a funnel or as a diffuser, the latter capable of creating a higher pressure gradient, able to channel the input flow and accelerate it in correspondence with the turbines.

Anyhow the turbines must be positioned before the vortex shedding edges so they can benefit from a flow perfectly directed to the rotor axis. Thanks to the possibility of channeling the wind, this solution is particularly suitable for horizontal axis turbines (HAWT) that can take advantage of a large section undisturbed air flow, obtaining good yields in the production of electrical energy due to the possibility of installing large rotors.

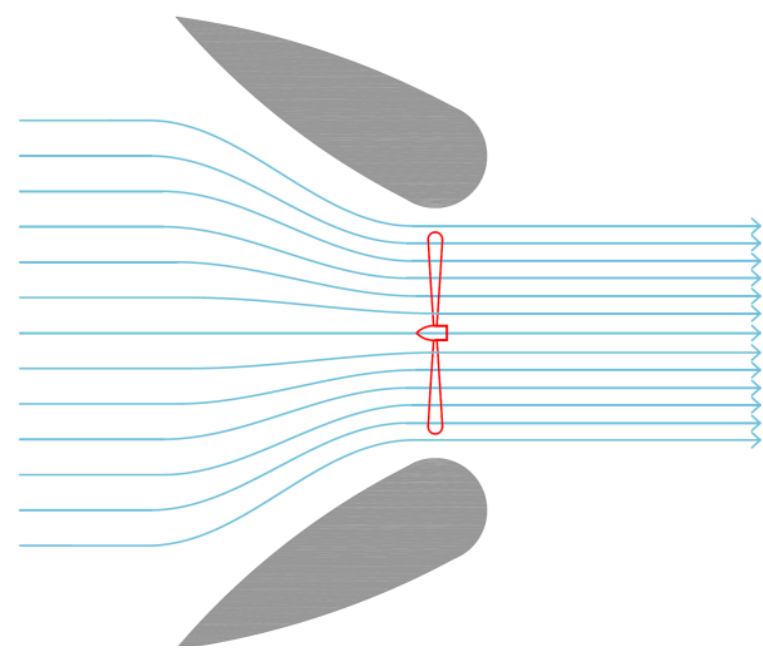

Fig. 8. BAWT between buildings.

In the World Trade Center in Bahrain, designed by Atkins (Fig. 9), the two sail-shaped buildings inclined at $45^{\circ}$ channel the air to three horizontal axis rotors of $29 \mathrm{~m}$ in diameter (225 $\mathrm{kW}$ each one), which are able to produce almost $15 \%$ of the energy needs of the building.

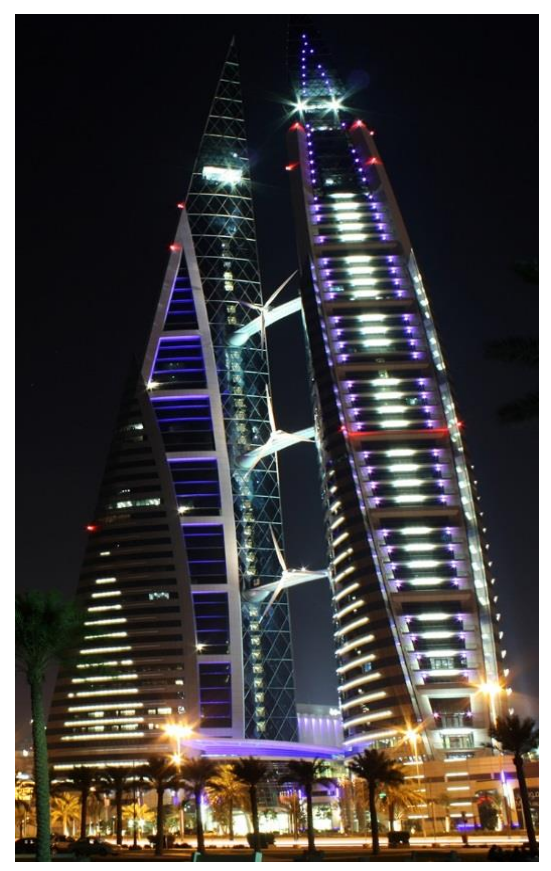

Fig. 9. Bahrain WTC [8].

\section{BAWT Inside Air Conducts throughout Buildings}

Another architectural solution for the exploitation of wind energy involves the placement of turbines inside the building, in order to use the difference in air pressure generated by the winds that affect the opposing facades (passing wind ventilation) (Fig. 10)

A building hit by the wind builds up the air in motion on the windward side resulting in an area of relatively high pressure. On the leeward side instead, a shadow of the wind with a 
relatively low pressure is created. The presence of two opposite openings on the windward and on the leeward determines an air current which can be used to power a wind generator. The generated airflow is proportional to the difference in wind pressure existing in correspondence of the entrance and exit apertures, their overall size and the dimensional ratio between the openings.

When the openings are located on two opposite sides the solution is effective only in areas characterized by constant prevailing winds that blow in a direction perpendicular to the openings plane. On the other hand in case of variable winds it is necessary to provide interconnected openings on all the four sides in order to exploit winds at $360^{\circ}$. This way maximum efficiency is reached with winds oriented at $45^{\circ}$ to the plane of any facade.

Anyhow the architectural constraints on the air conducts size require the use of small rotors, but the air uptake and acceleration ability ensures a good energy yield.

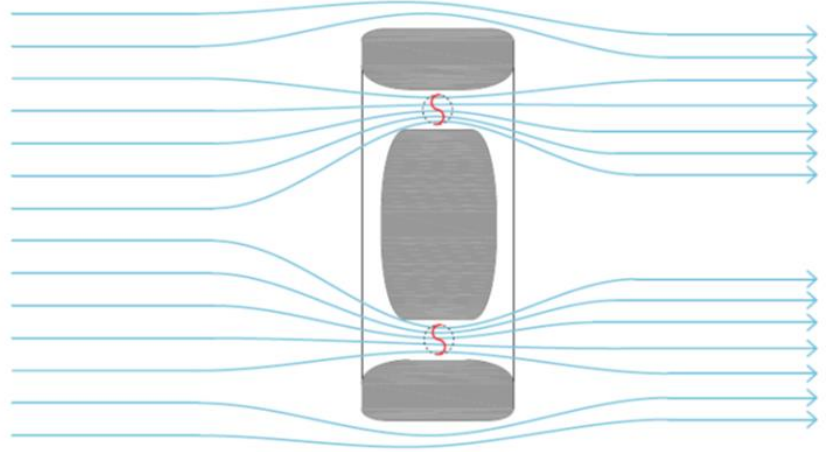

Fig. 10. BAWT inside air conducts throughout buildings.

In Pearl River Tower in Guangzhou, China, designed by SOM, there are corridors at the tech levels able to accelerate the air up to 2.5 times to feed the vertical axis turbines (Fig. 11). Similarly, Pertamina Energy Tower, under construction in Jakarta, by the same studio, will have at the top of its 530 meters a real "funnel" to channel the prevailing winds to wind turbines.

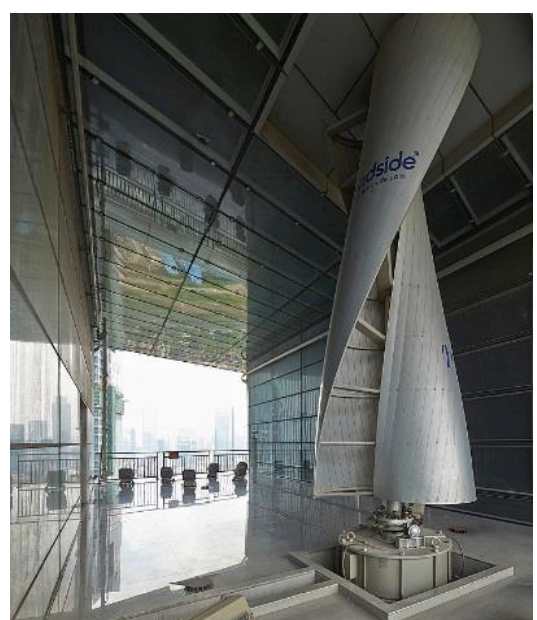

Fig. 11. Savonius VAWT inside Pearl River Tower - Guangzhou [9].

\section{TECHNICAL SOLUTIONS FOR BUILDINGS}

Nowadays on the market there are many models of VAWT turbines with vertical axis, with different dimensions and characteristics according to the use (see Table II). The power ranges from $200 \mathrm{~W}$ to $10 \mathrm{~kW}$ with an energy output that exceeds $17,000 \mathrm{kWh} /$ year when the annual average wind speed is around $12 \mathrm{~m} / \mathrm{s}$.

The most widely used material for their manufacture is aluminum, since both the Savonius turbines and the Darrieus use blades with fixed chord geometry, that are well suited to printing or extrusion production processes. Blades of Darrieus and Gorlov turbines often employ glass fiber and carbon fibers.

\section{A. Darrieus and Gorlov Turbines}

Darrieus turbines, and their development, Gorlov turbines, constitute the best solution to obtain maximum energy production. They are the only turbines to reach $10 \mathrm{~kW}$ power generators, although with pole-mounted models which are effective only for rooftop installed BAWT solutions (UGE 9M, Kessler Spinwind). With the same generator power, yields are generally higher than traditional Savonius solutions (a UGE Vision Air 5 with $3.2 \mathrm{~kW}$ of power promises 4000 $\mathrm{kWh} /$ year of electricity production at an average speed of 5.5 $\mathrm{m} / \mathrm{s}$, while a comparable Savonius model, Helix Wind S594, does not reach 3,000 $\mathrm{kWh} /$ year even with a higher average speed $-7 \mathrm{~m} / \mathrm{s}$ - and a more powerful generator $-4.5 \mathrm{~kW}$ ). Energy yields in the order of $14 \mathrm{MWh} /$ year are obtained with an average wind speed of $5.5 \mathrm{~m} / \mathrm{s}$. Their structure is inherently more fragile than the Savonius, and they need braking systems in case of excessively fast winds (models like the Kessler Spinwind do not work with wind speeds over $16 \mathrm{~m} / \mathrm{s}$ ).

\section{B. Savonius Turbines}

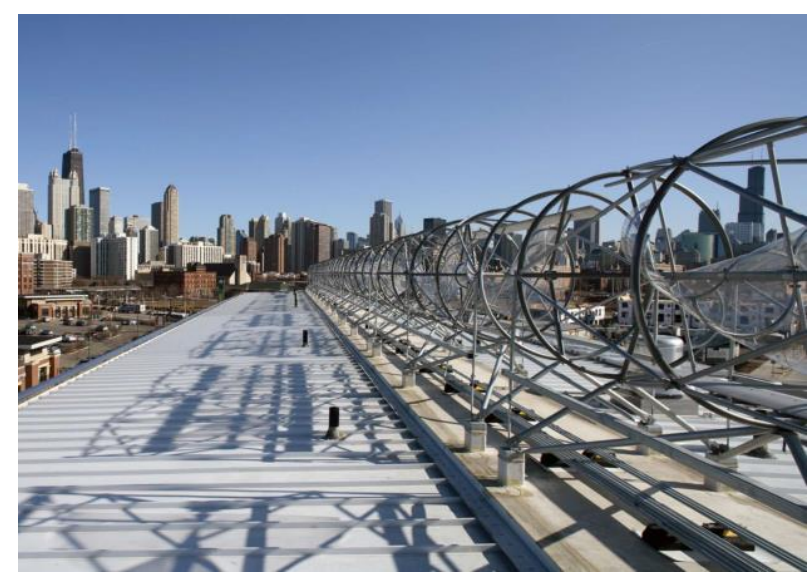

Fig. 12. Aerotecture turbines on Mercy Housing Lakefront rooftop Chicago [10].

The Savonius turbines, basing their operation on wind drag more than wind lift, are limited by the tangential speed of the blades, which in any case cannot exceed the speed of the wind pushing them. Although they are quicker to start than the Darrieus or Gorlov (products like Turbine Energy already begin to produce electricity with winds of $1.5 \mathrm{~m} / \mathrm{s}$ ), they need higher air speed to perform at their best, managing to maintain productivity even with winds exceeding $30 \mathrm{~m} / \mathrm{s}$ (with an annual average rate of $18.5 \mathrm{~m} / \mathrm{s}$ a Venger Wind V2 Turbo produces 23,400 $\mathrm{kWh} /$ year).

More advanced models with fixed stators in addition to the conventional rotors help to locally accelerate the air in order to increase performance: a Turbina Energy $4 \mathrm{~kW}$ with stators 
has an annual output which is more than double compared to a conventional Helix Wind S594 at the same average speed, and the Venger WindV2 Turbo produces $70 \%$ more than the same model without stators $(17,600 \mathrm{kWh} /$ year against 10,900 , with an average speed of $12 \mathrm{~m} / \mathrm{s}$ ). These characteristics make them suitable for installation in air conducts inside the building or adhering to the roof and facades, where they are able to withstand turbulences better than the Darrieus turbines.

Other VAWT models available on the market, include the Aeroturbines (Fig. 12), produced by Aerotecture, which can also be mounted horizontally, essentially becoming HAWT, as in the installation on the roof of the Mercy Housing
Lakefront in Chicago by Murphy/Jahn Architects. There, eight turbines take advantage of the prevailing winds from North-East and from South-South West without breaking the strict local height limits for buildings, which would have prevented the traditional vertical mounting.

On the other hand, the TR Innovative iWind is a mixed-type VAWT turbine, with a Savonius rotor inside and Darrieus H shaped blades outside.

Thanks to their small size ( $1.5 \mathrm{~m}$ high and $1.0 \mathrm{~m}$ in diameter) and lightness (carbon fiber blades) they promise easy installation as well as excellent performance (theoretically $10,000 \mathrm{kWh} /$ year with a speed of $4 \mathrm{~m} / \mathrm{s}$ and a $6 \mathrm{~kW}$ generator).

TABLE II: CHARACTERISTICS AND PERFORMANCE OF MAIN VAWT TURBINES AVAILABLE ON THE MARKET (FIG. 13-FIG.21)

\begin{tabular}{|c|c|c|c|c|c|c|c|}
\hline Producer & Model & $\begin{array}{c}\text { Power } \\
\mathbf{k W}(\mathbf{m} / \mathbf{s})\end{array}$ & $\begin{array}{c}\text { Capacity } \\
\text { kWh/year } \\
(\mathrm{m} / \mathrm{s})\end{array}$ & Height m & Swept area $\mathbf{m}^{2}$ & $\begin{array}{l}\text { Minimum } \\
\text { production } \\
\text { speed m/s }\end{array}$ & Material \\
\hline \multicolumn{8}{|c|}{ Gorlov Turbines } \\
\hline UGE & Hoyi & $0,2(12)$ & n.d. & 1,3 & 0,84 & 2,5 & Glass Fiber \\
\hline UGE & Vision Air3 & $1,0(14)$ & $770(5.5)$ & 3,2 & 5,76 & 4,0 & Glass Fiber \\
\hline UGE & $4 \mathrm{~K} \mathrm{GT}$ & $4,0(12)$ & $10.000(7)$ & 4,6 & 13,8 & 3,5 & Carbon Fiber \\
\hline UGE & Vision Air5 & $3,2(14)$ & $4.000(5,5)$ & 5,2 & 16,60 & 4,0 & Glass Fiber \\
\hline UGE & $9 \mathrm{M}$ & $10,0(12)$ & $14.000(5,0)$ & 9,6 & 61,40 & 3,5 & $\begin{array}{c}\text { Glass Fiber and } \\
\text { Steel }\end{array}$ \\
\hline \multicolumn{8}{|c|}{ Darrieus Turbines } \\
\hline Venger Wind & V300 & $0,3(14)$ & $661(8)$ & 1,0 & 1,0 & 3,5 & $\begin{array}{l}\text { Vetronite and } \\
\text { steel }\end{array}$ \\
\hline Ragosolar & SL30 & $3,0(12)$ & $10.000(8)$ & 3,5 & 10,5 & 3,0 & Carbon Fiber \\
\hline Kessler & Spinwind & $10,0(12)$ & n.d. & 14,2 & 40,0 & 3,0 & Aluminum \\
\hline \multicolumn{8}{|c|}{ Savonius Turbines } \\
\hline $\begin{array}{l}\text { Helixwind } \\
\text { turbine }\end{array}$ & S594 & $4,5(7)$ & $3.000(7,0)$ & 6,0 & 5,88 & 5,0 & Aluminum \\
\hline $\begin{array}{l}\text { Helixwind } \\
\text { turbine }\end{array}$ & S322 & $2,0(7)$ & $1.500(7,0)$ & 3,3 & 3,19 & 5,0 & Aluminum \\
\hline Venger Wind & V1 & $2,0(18,5)$ & $5.400(12)$ & 3,6 & 3,4 & 4,0 & Aluminum \\
\hline Venger Wind & $\mathrm{V} 2$ & $4,5(20,5)$ & $10.900(12)$ & 5,7 & 6,2 & 4,0 & Aluminum \\
\hline Venger Wind & V2 turbo & $4,5(15,2)$ & $17.600(12)$ & 5,7 & 6,2 & 4,0 & Aluminum \\
\hline Kliux & Zebra & 1,8 (n.d.) & $3.717(7)$ & 3,1 & 7,3 & 3 & $\begin{array}{c}\text { Expanded } \\
\text { polyurethane }\end{array}$ \\
\hline Turbina Energy & $1 \mathrm{kw}$ & $1,0(14)$ & $1.820(7)$ & 1,9 & 2,0 & 1,5 & $\begin{array}{c}\text { Aluminum and } \\
\text { Steel }\end{array}$ \\
\hline Turbina Energy & $4 \mathrm{kw}$ & $4,0(14)$ & $8.130(7)$ & 3,2 & 6,7 & 1,5 & $\begin{array}{c}\text { Aluminum and } \\
\text { Steel }\end{array}$ \\
\hline
\end{tabular}

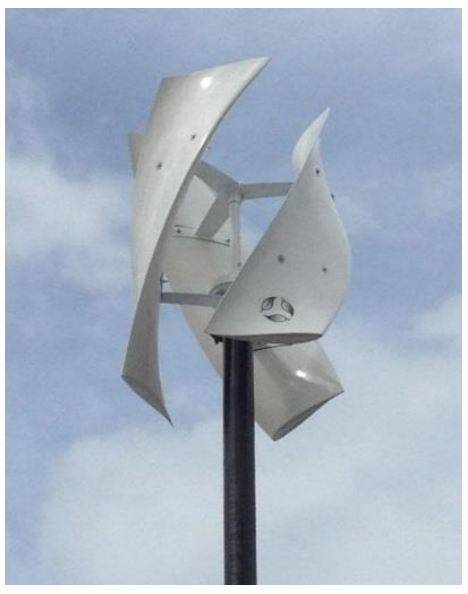

Fig. 13. UGE Hoyi.

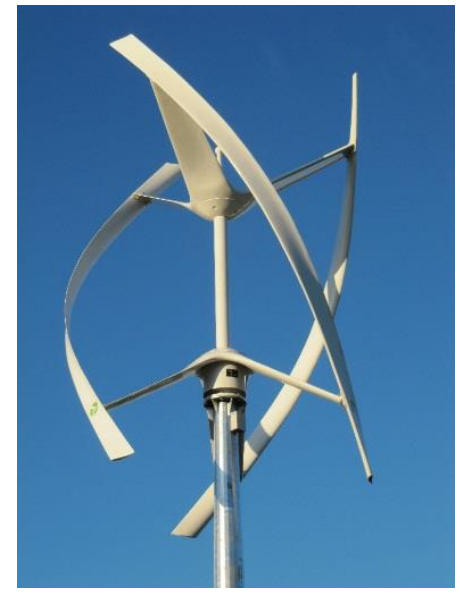

Fig. 14. UGE 4K GT.

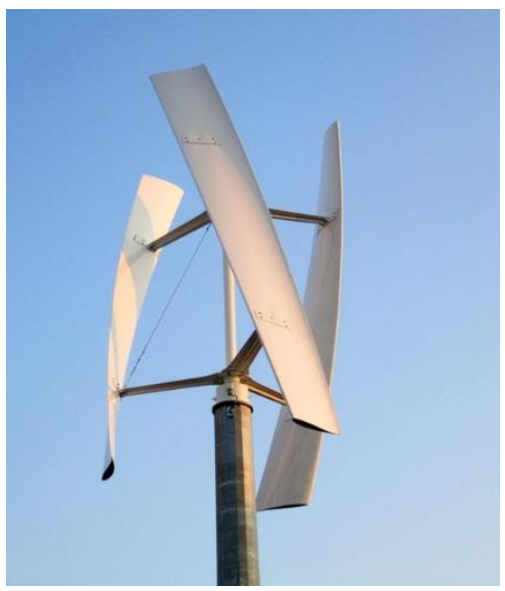

Fig. 15. UGE 9M. 


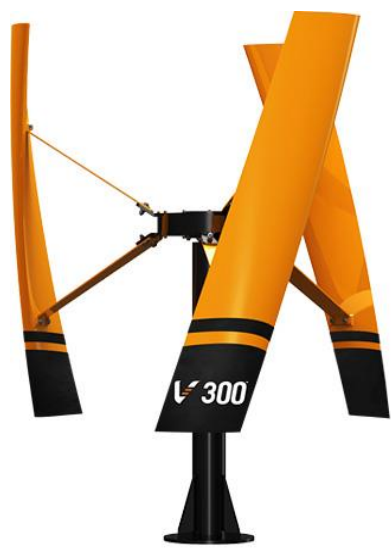

Fig. 16. Venger Wind V300.

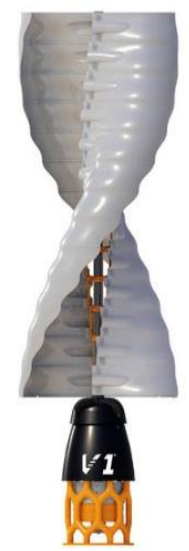

Fig. 19. Venger Wind V1.

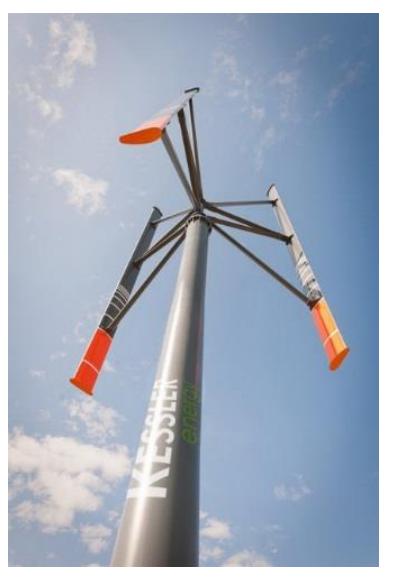

Fig. 17. Kessler Spinwind.

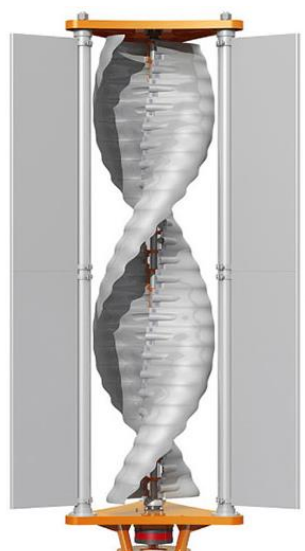

Fig. 20. Venger Wind V2 Turbo.

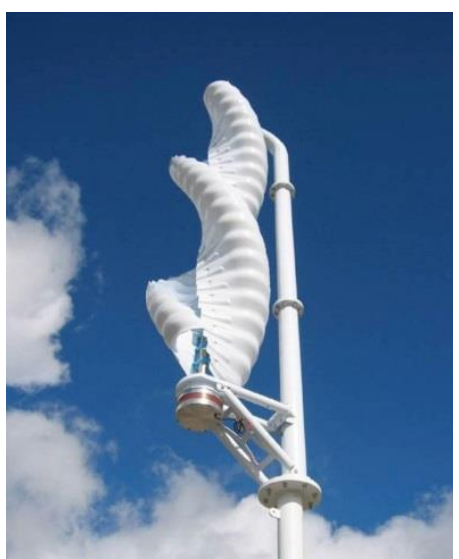

Fig. 18. Helixwind S594.

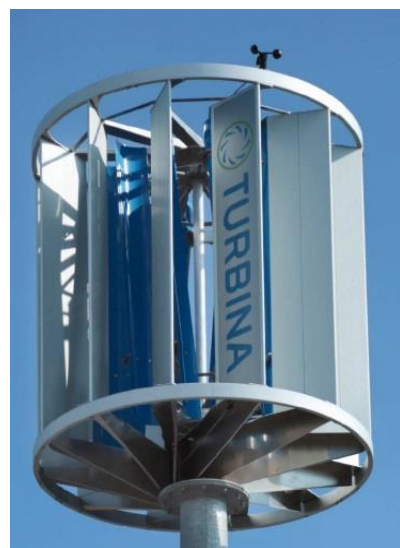

Fig. 21. Turbina Energy 1kW
Among horizontal axis turbines suitable to be building integrated, there is the Architectural Wind AVX1000 of AeroVironment (Fig. 22), which is able to generate $1000 \mathrm{~W}$ at $13 \mathrm{~m} / \mathrm{s}$ with an annual productivity of 2,500 kWh at $7.2 \mathrm{~m} / \mathrm{s}$. The installation of 20 generators on the roof of the Logan International Airport in Boston has allowed the building to achieve a LEED Gold certification, and the location turned out to be optimal, allowing speeds $15 \%$ and returns 50\% better than traditional pole mounted installations.

Finally, very interesting is the Archimedes Liam F1 (Fig. 23), a horizontal axis turbine with a spiral rotor developed by a Dutch company inspired by the Archimedes screw and the nautilus shell. Unlike normal blades functioning by lift (horizontal turbines, Darrieus) or drag (Savonius), the spiral collects the kinetic energy of the wind on a surface always perpendicular to the flow direction, managing to nullify output air speed and, according to the developers, promising efficiency up to $80 \%$, while the standard generators do not go beyond $25-50 \%$ in production. Other advantages are the good reactivity (minimum speed of $0.9 \mathrm{~m} / \mathrm{s}$ ) and the ability of the rotor to self-align.

\section{Innovative Products}

The recent development of the technology sector of micro vertical wind systems makes it an object of intense research and development, aimed at improving the performance and versatility of use. This can be achieved through the integration of new technologies such as magnetic levitation rotors to reduce friction, the introduction of innovative production processes such as 3D printing, up to completely new and futuristic technological and typological approaches, such as the Invelox, Ewicon and NanoventSkin prototypes.

\section{D. $3 D$ Printing}

The research around micro wind turbines is also covering the production process with the introduction of 3D printing technology to create customized turbines. In fact the Polish company Omni3D has recently developed the prototype of a $3 \mathrm{D}$ printed wind turbine that can generate 300 watts of clean power, enough to charge smartphones, laptops, light bulbs and other small gadgets. Thanks to the small size the Air Energy 3D can be carried in a backpack and used anywhere. The project database is open source to promote the diffusion of renewable energy sources.

\section{E. Invelox}

The new Invelox turbine (Fig. 24), developed by the SheerWind engineers in Minnesota, relies on an innovative design that provides a wind acceleration duct immediately before the turbine itself. The system is equipped with a funnel-shaped structure with multiple openings in the upper part in order to catch breezes from any direction, even with speeds below $1 \mathrm{~m} / \mathrm{s}$. The passage of the air in the wind turbine conduct accelerates the flow thanks to the Venturi effect, channeling it towards the opening to the ground where a traditional turbine is placed. This turns the kinetic energy of the wind into electricity like more traditional systems. According to the developers, tests have shown that the invention would be able to obtain an output $600 \%$ higher than the turbines on the market with the same size, with lower installation (between $7 \%$ and $11 \%$ ) and management costs (up to $45 \%)$. 


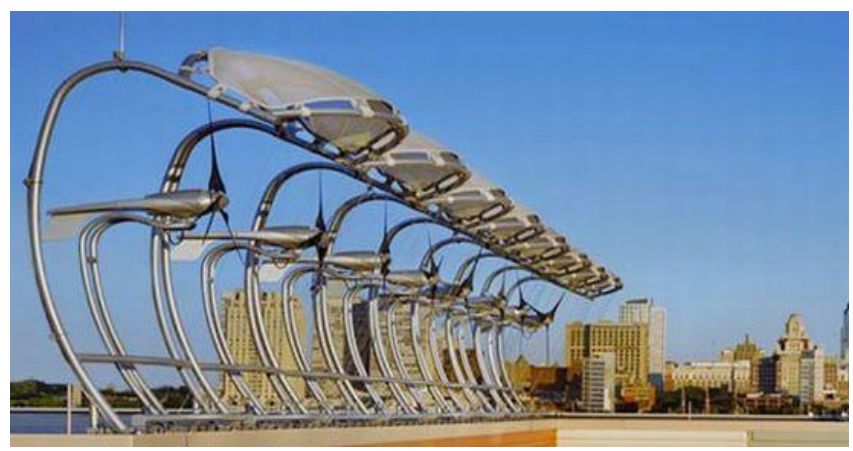

Fig. 22. AeroVironment AVX 1000 wind turbines.

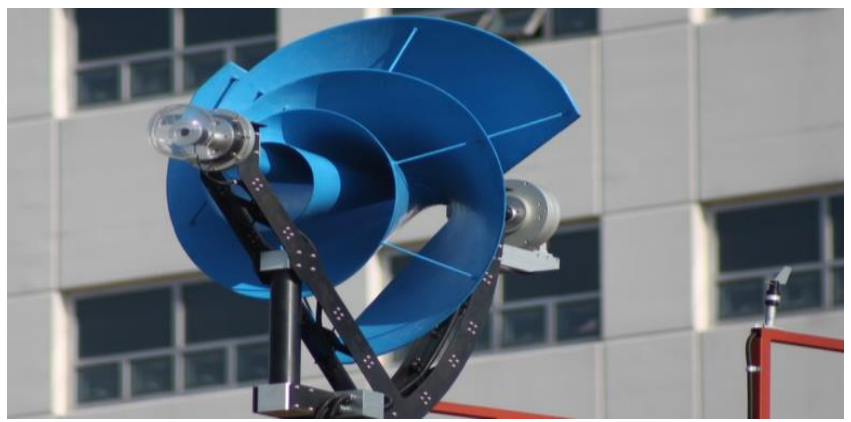

Fig. 23. Archimedes Liam F1 HAWT with spiral rotor.

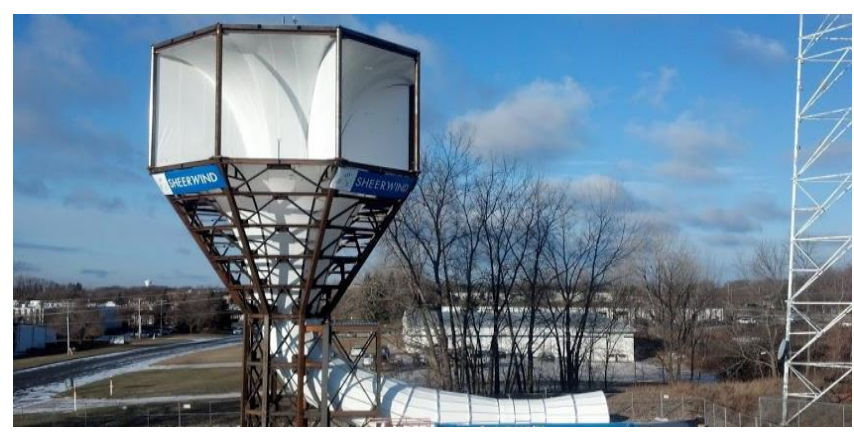

Fig. 24. Invelox wind turbine.

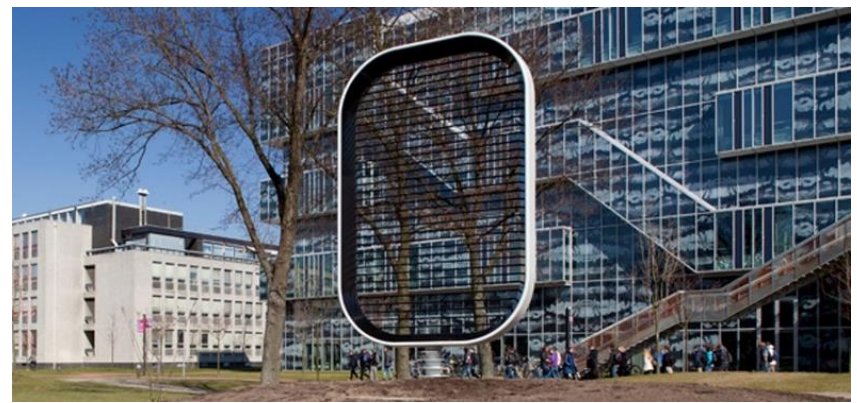

Fig. 25. Ewicon wind turbine.

\section{F. Ewicon}

Researchers of the Faculty of Engineering of the Delft University of Technology have developed an innovative wind turbine named Ewicon (Electrostatic Windenergy Convertor) (Fig. 25). The system is an electrostatic wind energy converter which has nothing of the appearance of a traditional turbine. Designed by Mecanoo, Ewicon is a system without moving parts, able to create potential energy using charged particles in this case, water droplets. The unit consists in a rectangular frame with a series of horizontal tubes, each equipped with various electrodes and nozzles in order to continuously release positively charged water particles into the atmosphere. When moved by the wind in the opposite direction to the electric field, they change the electrodes voltage creating an electric potential difference. According to the developers, the system can easily be installed both on land and off-shore like conventional turbines, but the design is particularly suited to urban areas due to the compactness and the absence of noise or shadows.

\section{G. Nano VentSkin}

Designer Agustin Otegui proposes the integration of micro wind turbines on a surface made of photovoltaic cells, through the use of organic nanomaterials. The surface structure of NanoVentSkin absorbs solar and wind energy and, through its nano-fibers, supplies energy to electricity converting units. At the same time each micro turbine also functions as an air filter, absorbing $\mathrm{CO}_{2}$ from the environment. In a similar way to human skin, each NanoVentSkin panel has a sensor on each corner connected to a reservoir of biological material. When a micro-wind turbine has a fault or breaks, it sends a signal to the central system and the building material (microorganisms) is sent through to regenerate the specific area through a self-assembly process.

\section{H. Solar Ivy}

This system, patented by New York based Solar Ivy, is inspired by climbing plants such as ivy, and consists of small and thin photovoltaic panels able to capture energy from the sunlight and the wind. Each polyethylene 'leaf' has a thin film photovoltaic cell and a piezoelectric generator able to turn the shaking induced by the wind into electrical energy, resulting in a mini hybrid system for electricity generation.

\section{CONSIDERATIONS ON THE PRODUCTIVITY OF VAWT WIND TURBINES}

As widely stated, VAWT wind turbine technology is now mature enough to allow larger scale use in urban centers and on buildings in particular.

Therefore most important becomes the competitiveness analysis of these systems compared to photovoltaic installations. With this aim, in relation to the various possible climatic conditions of wind and solar radiation, the performance of a Darrieus turbine, of a Savonius turbine and of a monocrystalline silicon photovoltaic module have been compared in terms of both electric productivity and cost of generated energy. The data used for the analysis were taken from specifications provided by the manufacturers (Table III). The results are shown in the graph of Fig. 26 that allows to quickly verify the cost-effectiveness of a solution compared to the other depending on wind and solar radiation conditions.

The comparison between the two turbines types shows how the Darrieus model always present a higher production of electricity per power unit for any wind speed compared to the Savonius model, even in case of high deviations of the average annual wind speed compared to the minimum and maximum average. However in terms of produced energy cost for average annual wind speeds exceeding $12 \mathrm{~m} / \mathrm{s}$ the Savonius is more convenient. The production of electrical energy of Darrieus turbines remains in fact constant over 9 $\mathrm{m} / \mathrm{s}$, while the production of the Savonius increases with the increase of the wind speed without operating limits. 
TABLE III: COMPARISON BETWEEN DARRIEUS AND SAVONIUS WIND TURBINES AND PV SYSTEMS

\begin{tabular}{|c|c|c|c|c|c|c|c|c|c|c|}
\hline \multirow{2}{*}{$\begin{array}{c}\text { Average } \\
\text { Annual } \\
\text { Wind } \\
\text { Speed } \\
(\mathrm{m} / \mathrm{s})\end{array}$} & \multicolumn{3}{|c|}{$\begin{array}{c}\text { UGE 4K GTDarrieusTurbine } \\
4 \mathrm{~kW}-20.000 €\end{array}$} & \multicolumn{3}{|c|}{$\begin{array}{c}\text { Helix Wind S594 Savonius } \\
\text { Turbine } 4,5 \mathrm{~kW}-13.500 €\end{array}$} & \multicolumn{4}{|c|}{$\begin{array}{l}\text { Schott Perform POLY 250W PV Panel } \\
2500 € / \mathrm{kW}\end{array}$} \\
\hline & $\begin{array}{l}\text { Productivity } \\
(\mathrm{kWh} / \mathrm{kW})\end{array}$ & $\begin{array}{l}\text { Produced } \\
\text { Energy } \\
\text { kWh/yr }\end{array}$ & $\begin{array}{c}\text { Energy } \\
\text { Cost } \\
(€ / \mathrm{kWh}) \mathrm{yr}\end{array}$ & $\begin{array}{l}\text { Productivity } \\
(\mathrm{kWh} / \mathrm{kW})\end{array}$ & $\begin{array}{l}\text { Produced } \\
\text { Energy } \\
\text { kWh/yr }\end{array}$ & $\begin{array}{c}\text { Energy } \\
\text { Cost } \\
(€ \mathrm{a} / \mathrm{kWh}) \\
\mathrm{yr} \\
\end{array}$ & $\begin{array}{l}\text { Annual } \\
\text { Solar } \\
\text { Irradiance } \\
\mathrm{kWh} / \mathrm{mq}\end{array}$ & $\begin{array}{l}\text { Productivity } \\
\text { kWhe/kWp }\end{array}$ & $\begin{array}{l}\text { Productivity } \\
\text { kWhe/mq }\end{array}$ & $\begin{array}{c}\text { Energy } \\
\text { Cost } \\
(€ / \mathrm{kWh}) \mathrm{yr}\end{array}$ \\
\hline 1 & 0 & 0 & - & 0 & 0 & - & 500 & 446 & 55,78 & 5,60 \\
\hline 2 & 250 & 1000 & 20,00 & 0 & 0 & - & 750 & 669 & 83,67 & 3,73 \\
\hline 3 & 500 & 2000 & 10,00 & 0 & 0 & - & 1000 & 893 & 111,56 & 2,80 \\
\hline 4 & 750 & 3000 & 6,67 & 10 & 45 & 300,00 & 1250 & 1116 & 139,45 & 2,24 \\
\hline 5 & 1250 & 5000 & 4,00 & 110 & 495 & 27,27 & 1500 & 1339 & 167,34 & 1,87 \\
\hline 6 & 1875 & 7500 & 2,67 & 220 & 990 & 13,64 & 1750 & 1562 & 195,23 & 1,60 \\
\hline 7 & 2500 & 10000 & 2,00 & 445 & 2000 & 6,74 & 2000 & 1785 & 223,13 & 1,40 \\
\hline 8 & 3250 & 13000 & 1,54 & 780 & 3510 & 3,85 & 2250 & 2008 & 251,02 & 1,24 \\
\hline 9 & 4000 & 16000 & 1,25 & 1110 & 4995 & 2,70 & 2500 & 2231 & 278,91 & 1,12 \\
\hline 10 & 4000 & 16000 & 1,25 & 1445 & 6500 & 2,08 & 2750 & 2454 & 306,80 & 1,02 \\
\hline 11 & 4000 & 16000 & 1,25 & 1780 & 8010 & 1,69 & 3000 & 2678 & 334,69 & 0,93 \\
\hline 12 & 4000 & 16000 & 1,25 & 2110 & 9495 & 1,42 & & & & \\
\hline 13 & 4000 & 16000 & 1,25 & 2445 & 11000 & 1,23 & & & & \\
\hline 14 & 4000 & 16000 & 1,25 & 2780 & 12510 & 1,08 & & & & \\
\hline 15 & 4000 & 16000 & 1,25 & 3110 & 14000 & 0,96 & & & & \\
\hline 16 & 4000 & 16000 & 1,25 & 3330 & 15000 & 0,90 & & & & \\
\hline
\end{tabular}

As for the comparison with PV systems, it is apparent that for values of solar irradiance between 1000 and $1500 \mathrm{kWh} / \mathrm{m}^{2}$ (corresponding to the average European values), wind systems are competitive in terms of produced energy cost for average annual wind speeds between 6 and $8 \mathrm{~m} / \mathrm{s}$ for the Darrieus turbines and 9 and $11 \mathrm{~m} / \mathrm{s}$ for the Savonius.

A $4 \mathrm{~kW}$ Darrieus turbine $4.5 \mathrm{~m}$ high (cost about 20,000 €) produces at $8 \mathrm{~m} / \mathrm{s}$ approximately $13,000 \mathrm{kWh}$ per year, corresponding to the production of more than $90 \mathrm{~m}^{2}$ of polycrystalline photovoltaic panels exposed to a solar irradiance of $1250 \mathrm{kWh} / \mathrm{m}^{2}$ (cost over $€ 27,000$ ).

Regardless of wind speed, wind systems also provide a viable alternative to photovoltaic systems in the case of small available surfaces or lack of sunlight access.

Obviously, in view of the need for wind power plants to maintain a minimum distance between the generators (at least 4 times the diameter), the possibility of installing more turbines depends on the geometry of the roof and the available power may be less than the one reached by the use of a photovoltaic system installed on the same surface. In such situations the Savonius turbines, which require a lower minimum distance $(5 \mathrm{~m})$ in comparison to the Darrieus, may allow a higher installed power.

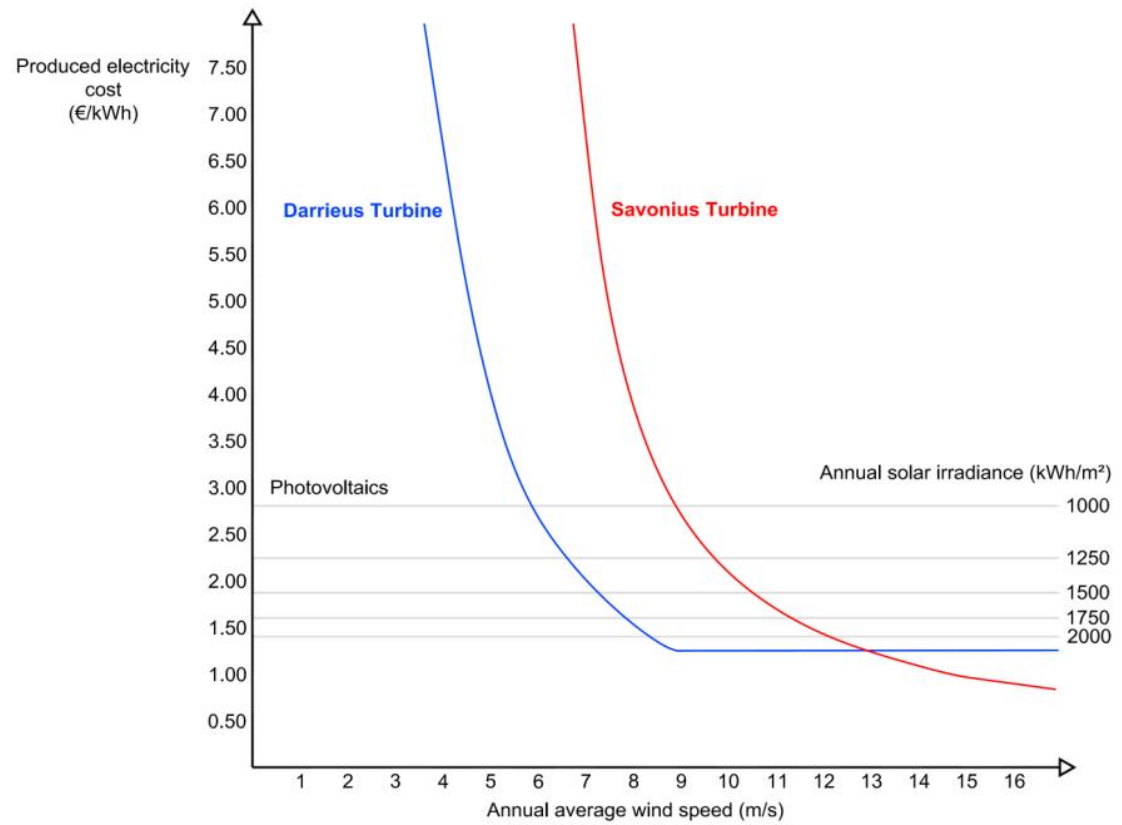

Fig. 26. Produced energy cost comparison between a Darrieus turbine, a Savonius turbine and a PV polycristalline silicon system. 


\section{CONCLUSIONS}

Small vertical wind turbines can be an effective solution for the production of renewable energy with the aim of promoting zero energy buildings and the urban model of distributed power generation. In relation to the influence of wind conditions on turbines' performance is absolutely essential, however, to carry out a thorough environmental analysis of the wind resource prior to the installation in order to identify the most suitable turbine model and its optimal location. Even in the presence of a good average wind speed, not all sites can in fact be suitable for the installation of wind energy systems. Maximum and minimum wind speed values that deviate much from the annual average can instead determine the failure of a particular turbine model over another.

In consideration of the interaction between building shape and wind intensity and direction, it is also important, in the case of new constructions, for the design team to work from the beginning alongside fluid dynamics experts in order to identify architectural forms able to maximize the eventual production of wind energy (BAWT).

Equally important for the diffusion of such systems, as well as for photovoltaics, is to define unambiguous standards for performance representation (reference speed for power and production measurement, etc.), to allow a true comparison between different products and to direct users and developers in relation to the environmental characteristics of the site. Although several models are nowadays available on the market, on the performance side it is difficult to gather reliable data from many manufacturers, regarding power or certain indications on obtainable energy or noise emission values.

Finally, it is necessary to intervene to prevent in any way products not meeting the stated performance from entering the market. With this purpose the International Energy Agency (IEA), as part of the Wind Implementing Agreement, has launched Task27 "Consumer Labelling of Small Wind Turbines" with the aim of developing international standards with regard to the quality and performance of small wind turbines. The final product of the task is the publication of an international guide of this industry sector, the "Recommended Practice for Consumer Labelling of Small Wind Turbines", that takes into account the IEC61400-2 Design Requirement for Small Wind Turbines regulation.

\section{REFERENCES}

[1] 2014 Half - Year Report, WWEA, 2014, p. 8.

[2] Small Wind World Report 2014, WWEA, May 2014, p. 20.

[3] Annual Report 2013, EWEA, June 2014, p. 36.
[4] Perkins+Will Architects. (2012). Oklahoma medical research foundation. [Online]. Available: http://perkinswill.com.

[5] KMD Architects, "Public utilities commission building, San Francisco, California," 2012.

[6] HOK Group, Inc, "Greenway self-park building," 2012.

[7] G. Haws. (2012). Strata SE1 the lipstick elephant \& castle. [Online]. Available: https://www.flickr.com/photos/flash_homer.

[8] A. Donque. (2010). The world trade centre Bahrain at night. [Online]. Available: https://www.flickr.com/photos/allandonque.

[9] Skidmore, Owings \& Merrill LLP, "Pearl river tower - Sustainable design," 2011.

[10] Jahn Architects. (2007). Margot \& Harold Schiff Residences. [Online]. Available: http://architizer.com/projects/margot-harold-schiff-residences.

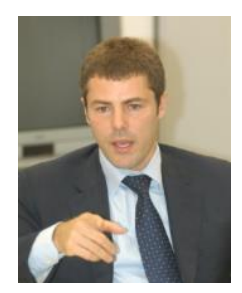

Marco Casini received his degree in environmental engineering (cum laude) in 1997 and Ph.D. degree in environmental engineering in 2002 at "Sapienza" University of Rome, Faculty of Engineering .

$\mathrm{He}$ is a professor of architecture technology, of technologies for buildings environmental design and of environmental certification of buildings at "Sapienza" University of Rome, Faculty of Architecture (since 2002). He is a member of the Teaching Faculty of the PhD in "Energy Saving and Energy Distributed Microgeneration" at the Graduate School of Architectural Science, CITERA, "Sapienza" University of Rome (since 2009). He is also a member of the Scientific Council of the Master's degrees in "Management of Heritage Real Estate" (since 2006), in "Preparation and Design of Components" (since 2009), in "B.I.M. Building Information Modeling" (since 2014) at the Faculty of Architecture "Sapienza" University of Rome. $\mathrm{He}$ has been the scientific director of the editorial board of the Journal "Ponte" since Feb. 2014. And he is a member of the Interregional Working Group for Sustainable Construction at the Italian Institute for Innovation and transparency in government procurement and environmental compatibility (since 2009); a member of the "Technical Committee for the evaluation of real estate estimates" of the Bank of Italy from 2006 to 2010. He has written many essays and articles on renewable energies, environment and sustainable building. He is an expert on environment and green buildings, carries out its research activities in the fields of ecological design, energy efficiency, smart materials, renewable energy sources and smart cities at the "Sapienza" University of Rome, Department of Urban Planning, Design and Architecture Technology, (PDTA) and Research Center CITERA, where he worked on major projects such as completion of "Regional system for the certification and accreditation of energy and environmental sustainability of buildings" (Protocollo ITACA Lazio) and the preparation of the "Sustainable Energy Action Plan of Rome (SEAP) in to the Covenant of majors European project.

$\mathrm{He}$ is the author of the books: Designing the Efficiency of Buildings, Certification of Energy and Environmental Sustainability (Roma, DEI, 2013, p. 274), Building the Environment. Tools and Methods of Environmental Design (Milano, Edizioni Ambiente, 2009, p. 400) and EMAS Eco-Management and Audit Scheme (Milano, IlSole24Ore, 2004, p. 324). 